November - 2004

\title{
Stealing the Goose: Copyright and learning
}

\author{
Rory McGreal \\ Athabasca University - Canada's Open University
}

\begin{abstract}
The Internet is the world's largest knowledge common and the information source of first resort. Much of this information is open and freely available. However, there are organizations and companies today that are trying to close off the Internet commons and make it proprietary. These are the "copyright controllers." The preservation of the commons and expanding access to digital content and applications are very important for distance educators. The educational exemptions for "fair use" in the United States and "fair dealing" in the Commonwealth countries are integral to any understanding of copyright, which was instituted for the dissemination of knowledge, and not, as is commonly believed, to protect the rights of the copyright owners. Copyright law was expressly introduced to limit their rights. Yet, these controllers are successfully turning a "copy" right into a property right. The traditional rights of learning institutions are being taken away. The balance for researchers should be restored. Research and learning must be allowed the broad interpretation that was intended in the original laws.
\end{abstract}

Keywords: copyright; intellectual property; infringement; Internet; stealing; balance

\section{Introduction}

They hang the man and flog the woman Who steals the goose from off the common But leave the greater villain loose Who steals the common from off the goose.

Anonymous 1764 or 1821

The Internet is the world's largest knowledge common and the information source of first resort according to Lyman and Varian (2003), who estimated that the available World Wide Web contained more than 167 terabytes (167 X $10^{12}$ bytes) of data organized into information of various sorts. Much of this information is open and freely available to any and all Internet users. However, like the landlords of old who fenced in the commons and drove out the "croppers," there are organizations and companies today that are trying to close off the Internet commons and make it proprietary. These organizations and companies are prosecuting individuals who are making use of the commons, while they themselves are free to take away the knowledge from the commons and make it unavailable.

The preservation of the commons and expanding access to digital content and applications, are very important for distance educators in particular. Access to this vast store of information forms a basis on which a wide variety of learning experiences can be built, both formal and informal. It 
is about universality, making learning available to anyone anywhere at anytime. The increasing availability of computers with online access is making the Internet commons integral to formal learning environments both on and off campus.

Created works form a priceless, shared heritage on which all knowledge is based. All learning is based on the accomplishments of the past. Recognizing that new ideas are seldom original and never appear first in their completed form, Isaac Newton in his letter to Hook, February 5, 1676 wrote: "If I have seen further, it is by standing on ye shoulders of Giants." Newton, as did other scientists of his generation, had full and open access to the works of others and thus he was able to build on this knowledge to "discover" his Laws of Motion. Mark Twain, commenting on the works of novelists was less gracious in his description: "We are all thieves" (Paine, 1917, p. 732).

Today, organizations of so-called "intellectual property" (IP) owners, and vendors of music, videos, and books, and other forms of codified information are closing off the commons. In this essay, I shall use the term "copyright controllers" to refer to both the owners and vendors, including the "big players" such as Disney, Bertelsmann, and Time/Warner/AOL and their organizations that together control much of the world's content (Barlow, 2002). They want to control "in infinite detail all use and duplication of material, and to monitor that use, and possibly charge for it on a transactional basis if they don't block it out of hand” (Lynch, 2001, p. 29).

Much of this assault on the commons is being led by the United States (U.S.), which is leading the world rush to protect IP. It is doing so by forcing other countries to toe their line. Australia was forced to accept the U. S. approach to IP protection in their free trade agreement with the U. S., reinforcing "Australia's reputation as one of the world's leading countries in protecting and enforcing intellectual property rights" (Australian Government Department of Foreign Affairs and Trade, 2004). The Australian journalist, Gittins (2004) warns about this U.S. push for "harmonisation" forcing other countries to copy U.S. laws, and then "act as policemen in prosecuting citizens who pirate American IP, enhancing the ability of U.S. companies to protect their rights in other countries' courts.” Even the Iraqi government has already been forced to toe the U.S. line on IP where defending IP rights is "a high priority" (U.S. Department of Commerce, 2004). The U.S. has placed 49 countries on its "priority watch list," and designated some of them for "Section 306" in which the U.S. can move directly to the application of trade sanctions, whenever a country is not adequately enforcing IP rights (U.S. Department of State, 2004). It is because of this worldwide assault by the copyright controllers that much of this paper is of necessity concerned with the copyright developments in the U.S. that are affecting all countries.

Enclosure of the Internet commons has been led by AOL, which has created one of the largest walled gardens. Otherwise known as "walled prisons" or "captive portals, they are websites or collections of closed websites that manages users' access to the content, directing them to specific content and/ or preventing them from accessing selected material. Walled gardens are often found on websites aimed at children to prevent them from accessing inappropriate content. Companies use them to direct surfers to specific sites for sales purposes or simply to keep them away from competitors, while offering them the illusion of online choice. America Online (AOL) is considered to be one of the most successful walled gardens. More than 85 per cent of AOL users never leave the walled garden and visit other areas of the Internet (SearchSecurity.com, 2004). Examples of other companies attempting to close off the commons include: Universal Studios fighting movie websites that want to link to film trailers on Universal's site (Cisneros, 1999); and Ticketmaster's attempts to stop Sidewalk from bringing potential ticket-buyers to the Ticketmaster page that sold tickets to the events announced on the Sidewalk website (Macavinta, 1997). 
Jesdanun (2001) reminds us that if the WWW creators had not wanted us to link they would have called it the "World Wide Straight Line." In a Danish court case, she argued that linking is a fundamental element of the Web, strengthening the commons. Oram (2001) argues that the copyright controllers are trying to force digital data to behave like objects in order "to bring the inconvenience of the physical world to the Internet” (p. 34).

The controllers argue against the commons referring to Hardin's (1968) "Tragedy of the commons" thesis, in which he postulates that a commons cannot last because, individuals acting in their own interest will exploit all the available resources. However, Hardin's thesis rests on "a world that is limited." Bandwidth and storage space available on the Internet is growing exponentially and there is little possibility of it ever becoming "limited." In addition, Hardin's theory is not entirely supported by history. Examples of commons and open ranges have survived in many parts of the world including the UK (English Nature, 2004), the U.S. (Davis, 2004), and other countries (Indiana University, 2004), and there is no sign of their imminent collapse.

\section{What is Copyright?}

The most serious threat to the Internet commons (and to those like distance educators who use it) is the assault on copyright. This attack comes from the copyright controllers. They are taking a concept that was originally intended to establish a balance promoting the spread of knowledge by providing advantages to both creators and consumers. The Owners are now attempting to reshape it into what Surowiecki (2002) calls "property-rights fundamentalism" - copyright as a mechanism for the protection of "property." By calling their intellectual creations "property," the copyright controllers have to "plant in the public mind the idea that cultural products (movies, recorded music, books) are 'property' in the same sense that your house and its contents constitute property" (Naughton, 2003). Bollier (2003) claims that the controllers are campaigning to "morph copyright into a content protection system” (p. 121).

Unfortunately, for the proponents of IP, historically, copyright did not emerge as a property right. Copyright was explicitly instituted to "encourage learning" in Great Britain (House of Commons, 1709) and developed from this concept to "promote the progress of science and the useful arts" in the U.S. Constitution U.S. Constitutional Convention, 1787). Copyright was not enacted for the purpose of protecting the rights of the author. Such an interpretation has been identified by Jaszi (2001) as the recasting of copyright as "para-copyright" or "pseudo-copyright.” Barlow (1996) argues that old laws like copyright cannot be made to work by "grotesque expansion or by force" (p. 10). In much of Europe, countries use the Napoleonic code and base their copyright laws on "le droit d'auteur" (author's right), but this is alien to the British common law tradition on which Commonwealth and U.S. laws are based.

Copyright in the common law is based on the premise that no one owns ideas and that creative works belong to everyone. Copyright protects only the expression of ideas and not the ideas themselves. Copyright holders possess a simple "copy" right that gives them an exclusive right to exclude others and otherwise control the expression of their ideas for a limited time. The creators or their assignees possess the "copy" right for a limited time. This was originally 17 years and has been extended since then. Bloom (2002) complained that whoever turned "copy right" into one word had to be a lawyer. We don't say "freespeechright" or "gunright" or "assemblyright" or "religionright."

This limited copy right was never intended to be a property right. Bell (2002) writes that the copyright owners have "co-opted the rhetoric of property" (p. 8). The term "intellectual property" 
was seldom used prior to its popularization following the establishment of the World Intellectual Property Organization (WIPO) by the United Nations in 1968 (United Nations, n.d.). Since then, owners of copyright on creative works have conducted a constant campaign with some significant success to transform copyright into a property right. They are extending the property label for intangible things like texts, songs, movies, and plays, as far as possible attempting to establish the view that any unauthorized use is stealing. Vaidhyanathan (2001), resting his argument on the U.S. Constitution, however, suggests that the term "intellectual policy" would be more appropriate, which considers copyright to be an incentive to create and distribute new works and not a restrictive property right. He argues that copyright is an incentive and nothing more.

Significantly, although the copyright controllers are vigorously pursuing the conversion of copyright into a property right, they are at the same time taking measures to limit the property rights of consumers through restrictive licensing. According to Katyal (2004) these restrictions relieve the buyer of the right to consume property, to use it harmlessly, to transfer property to another person and exclude anyone from entering, infringing, or interfering with their use and enjoyment of it. She notes that copyright controllers are trespassing on the privacy of consumers by spying on them using "extrajudicial surveillance" techniques. She further argues that "we have created a world in which the property rights of copyright owners are valued over the liberty, property, and privacy rights of others.” The content companies are clear "about their intentions to charge for every bit of data, stamp out the used CD market, and crush libraries by extinguishing 'fair use'“ (Vaidhyanathan, 2001, p. 182).

"Fair use" in the U.S. and "fair dealing" in the Commonwealth countries are the traditional exemptions to copyright allowed to the public and specifically to educational institutions for research and other uses such as parody, or quoting. If a use is fair, then the users do not need any permission to exploit the copyrighted materials. A significant difference is the limitation to research and private study in the fair dealing countries, whereas fair use in the U.S. also includes teaching.

Now, when a consumer buys software, music, videos, and e-books, they must accept licenses that restrict their traditional rights. They no longer have the right to fair use. They may be restricted to loading their software only once on one machine, they may not share e-books with their friends, and they are subject to online surveillance by the copyright controllers (or even by vendors of other products that they have not purchased).

The copyright owners argue that property rights and restrictive licenses are essential for their survival, and that they are an economic necessity. Yet, as Bollier (2003) points out, there are many profitable industries that are thriving without any copyright or patent protection. These include perfumes, recipes, clothes designs, furniture, car bodies, and monuments. The rock band The Grateful Dead, regularly grossed more than U.S. \$50 million per year without relying on copyright (Wilder, 2000). The successor group, The Dead, is continuing this open tradition. In fact, they positively encourage their fans to tape their concerts and share the tapes around, even providing a special area at concerts for recorders. This business model of public access is championed by one of their former lyricists, John Perry Barlow, who is a co-founder of the Electronic Frontier Foundation, which is actively opposing the enclosure of the Internet commons (Barlow, 1994). 


\section{History}

Ancient scribes (the earliest copiers) in writing the classics and sacred books of different religions were quite comfortable in excluding, substituting, amending, expanding, and abridging their materials. In the fourth century BC, Aristotle wrote: "Imitation is natural to man from childhood [and] the first things that he learns come to him through imitation” (Aristotle, 2004). The ancients had no proscriptions against copying or even plagiarism. Our ancestors' understanding of the world was housed in stories - not dogma. Story tellers had no "moral" right to protect their tales. No one questioned the right of anyone to copy these and other works. "The concept of copyright was utterly foreign to the ancient mind" (Harpur, 2004, p. 141).

[In many non-western traditions, although copying was also common, in many cases copying rights for stories and symbols were restricted to particular tribes, clans, or persons (Industry Canada, 2004b; McDonald, 1997). This paper does not address the rather special circumstances surrounding IP issues of aboriginal communities. Educators in developing countries might compare their situations with that of the U.S. when it was a developing country (See Khan, 2004)]

In Ireland in the sixth century there occurred the earliest known judgment on copyright. An Irish monk, Columcille, copied without permission St. Jerome's psalter, a hymn book belonging to St. Finnian, the abbot of another monastery. Finnian asked Columcille to return the copy and was refused. Finnian appealed to the High King of Ireland, King Diarmait, who pronounced the judgement in Finnians favour: "To every cow its calf to every book its copy." Columcille responded to this adverse judgement with force and met the king's men in battle at Cuildremne in 561. Columcille was triumphant and King Diarmait was exiled from Ireland, but as a result more than 3000 men lay dead (Thomas, 2004). Columcille was later also exiled to Scotland, where he is known as St. Columba (Concannon, 2004). It could be said that although he lost the court case, with the battle, he won his point. This battle resolved the copyright issue in favour of openness for more than a millennium. The Irish monks continued copying books, spread out from Scotland, and brought the enlightenment to Europe (Cahill, 1995).

The printing press, with its capacity to mass produce copies, came to Europe in the 15th century. There were few presses and many authors, so the printers gained control over the books that were produced, usually by paying authors a one-time fee. Monarchs found it easier to tax and control the few printers than tax all the authors, so they granted them monopolistic rights in return for taxes and censorship. The Stationers Company, which was made up of members of a printing guild, was granted a printing monopoly in 1557 in order to prevent the spread of Protestant writing in England (Editors, 2004). During the Cromwellian period, the print monopolies were strengthened although the censorship was then directed against opponents of Puritanism.

It is during this period that copying without referencing the author became socially unacceptable. Ben Johnson was one of the first authors to use the term "plagiary" in English with its current meaning. The Oxford English Dictionary provides an earlier reference from Montagu in 1621, who used the word "plagiarisme" in the sense of purloining someone's work (Oxford University Press, n.d.). Howard (1988) argues, therefore, that plagiarism is a historical construction rather than a moral category. Downes (2003a) acknowledges that plagiarism, while being mendacious, is not theft. Rather it is "a breach of trust between the plagiarizer and the reader . . . a misrepresentation of one's self as something one is not." 
Our modern concept of copyright in British common law has developed from the Statute of Queen Anne 1710 An Act for the Encouragement of Learning. It was passed for the purpose of promoting learning, specifically to encourage "learned men to compose and write useful books" (House of Commons, 1709). Up until then, the publishers could pass on their royal grants of copyright to their heirs in perpetuity. This Act was a consequence of the 1707 Act of Union with Scotland to form the United Kingdom of Great Britain. Scottish booksellers would not accept the English monopoly of the London Stationers' Company. This first copyright law had the purpose of breaking the Stationers' monopoly and so, it was not a mechanism for protecting copyright controller's rights as it is often portrayed nowadays. Copyright law was expressly introduced to limit their rights.

In the Statute of Queen Anne, copyright was wrested from the printers and vested in the authors. This right was limited to a maximum of 28 years, after which works entered the public domain. So in effect, this statute created the public domain - the intellectual commons. This is the most important aspect of this law for the public and for education. It created a body of works that could be copied, altered, adapted, or tweaked by anyone for amusement, profit, or enlightenment. In addition, Article IX gave a special exemption to universities to ensure that none of their traditional copying rights were affected. This was no coincidence, intellectuals like John Locke actively campaigned for the repeal of the monopoly in the book trade and strongly condemned the restrictions on science caused by the monopolies of the Stationers Company (Locke, 1692).

Forté (2000) explains: "Copyright isn't on a par with the right to life, liberty, fraternity and equality before the law. It's a privilege extended to us by our fellow citizens because they recognise the value they get out of our efforts." Copyright was never intended to be primarily a vehicle for protecting the rights of the copyright holders. On the contrary, copyright was initiated specifically to promote learning by removing the perpetual rights of the copyright controllers transferring the rights to the authors and imposing a reasonable time limit on their privilege.

Most of the colonies that formed the United States had laws that were based on the Statute of Queen Anne (Shirata, 1992). So it is not co-incidental that the U.S. Constitution echoes this purpose. It specifically refers to Congress's duty in Article I Section 8:

To promote the progress of science and useful arts, by securing for limited times to authors and inventors the exclusive right to their respective writings and discoveries (U.S. Constitutional Convention, 1787).

This was followed by the Copyright Act 1790: An Act for the Encouragement of Learning and it was signed by George Washington (Washington, 1790). Like the Statute of Queen Anne, this act (as the title suggests) was enacted specifically for the "encouragement of learning" and is meant to protect the rights of copyright holders only insofar as it serves that purpose.

Thomas Jefferson (1813) expressly opposed linking copy rights to property rights, writing "Inventions then cannot, in nature, be a subject of property." President Madison wrote that "incentive, not property, or natural law is the foundational justification for American copyright" (as cited in Vaidhyanathan, 2001, p. 43). So, there is no common law support for IP. It is a privileged monopoly, not a right. Since these laws were first enacted, the copyright controllers have waged a continuous war aiming to extend their rights at the expense of education and the general public. 


\section{Infringement - Not Stealing}

Copyright controllers distort the meaning of the words "stealing" and "theft" for their own purposes. Naughton (2003) contends that the use of such language "would make an excellent Orwellian case study." "Stealing" and "theft" have emotive value because they are considered to be evil acts by most people. They are proscribed activities in the Judaeo-Christian Ten Commandments, and in the sacred books of other religions. The copyright controllers use these words to strengthen their case for extending the meaning of copyright.

According to the Oxford English dictionary, however, "to steal" is defined as: "To take away dishonestly (portable property, cattle, etc., belonging to another) (Oxford University Press, 1989). As copying takes nothing away from anyone (the owners still possess their copy) and as intellectual content is not property, then copying content is not stealing. In the U.S., this interpretation was strengthened by a Supreme Court decision that:

infringement is not theft [as the infringer] did not assume physical control over the copyright nor wholly deprive its owner of its use ... infringement does not easily equate with theft, conversion, or fraud. . . The Copyright Act employs a separate term to define one who misappropriates: infringer (Dowling v. United States, 1985).

Given these facts, it is incorrect, and perhaps even dishonest, for the copyright controllers to use the term "stealing" in reference to copying materials. Nothing is taken "away" from anyone. The owner still has it. Jefferson (1813) put it this way: "He who receives an idea from me, receives instruction himself without lessening mine; as he who lights his taper at mine, receives light without darkening me.” When you copy without damaging or use someone's creative work and take ideas or impressions or methodologies or whatever from a creative work, or simply take enjoyment from it, you are NOT stealing, not from any religious, ethical, or legal point of view.

The so-called owners possess the copy right for the creation, not a property right. As Madison noted (see above) copyright is specifically not a property right. Stealing and theft as confirmed by both the Oxford and Merriam Webster (Merriam-Webster, 2004) dictionaries involves the taking of "property" belonging to another. Since, there is no property, it cannot be stealing.

The problem for copyright controllers is that they cannot find religious texts condemning "infringement" and so it is difficult for them to get public support using this legalistic terminology. The ancient religious writers, as we mentioned previously, were quite adept at copying and adapting the works of others and would doubtless have not found copying to be immoral. Without extensive copying in a manner that might today be considered to be infringement or even plagiarism, there would be no religious texts, nor classical literature. It is difficult for the copyright controllers to build a moral case against copying when the ancients actively encouraged it.

Rev. Frame (2002) notes that if it were a moral issue, then copyrights should never expire. "If it is morally wrong to copy a piece of music in June of 1989, it is also morally wrong to copy that same piece of music in June of 1991. (Moral principles, by their very nature, are eternal, as God is eternal)." As all human progress is based on copying, any society that adopted and followed this as a moral principle would not have progressed and would have stagnated. All human knowledge is based on copying. Can you imagine how well a prehistoric tribe would have survived if it had felt that copying spears or bows and arrows used by other tribes, was immoral? We have such a situation today where poverty-stricken countries are not permitted to copy the 
content and software applications created by the rich countries. They are being told that it is "stealing" if they deign to copy software, scholarly articles, and texts that might educate their people.

\section{Assault on Copyright}

So, infringement is not stealing, but that has not stopped the big companies from mounting an outright assault on the copy rights of consumers. Nadin (1997) noted that governments are quick to give up ideals like human rights, but they "raise a big fuss when it comes to copyright infringement" (p.36). As previously mentioned, the content companies are so powerful that IP laws asserting their interests were among the very first passed by the new Iraqi government (Associated Press, 2004).

More than 40 bills re-inforcing the IP interpretation of copyright have been introduced in the U.S. Congress since 1997 (Chartrand, 2000; Billboard.biz, 2004). These bills makes it a crime to share copies of copyrighted products even with family (No Electronic Theft (NET) Act, 1997) and makes it illegal (and even criminal) to circumvent protection mechanisms on software (Digital Millennium Copyright Act, 1998).

The European Union is getting on the quasi copyright bandwagon too with its Directive for the Enforcement of Intellectual Property Rights. It has been called the "nuclear weapon of IP law enforcement." Now copyright controllers have the right to raid homes of suspected infringers (European Union, 2003; Rupley, 2004).

The Sony Bono Copyright Term Extension Act (1998) is perhaps the most insidious act for educators, preventing hundreds of thousands of creative works published between 1923 and 1943 from entering the public domain. This could be considered to be "stealing" from the public. This act was introduced by the pop singer/ congressman, Sonny Bono, and strongly supported by Disney to prevent its content from entering the public domain. Some people call it the "Mickey Mouse” Preservation Act (Black, 2002; Levy, 2002) because every time Mickey is due to enter the public domain, the copyright is extended. There is no guarantee that there will not be a further extension of the Act after this 20 year period has ended. It could last "forever less a day" (U.S. Congress, 1998).

Jaszi (2001) emphasizes that the real concern is not about Mickey Mouse entering the public domain, but all the other content such as classical music, little-known films, etc. that get incidentally restricted in order to protect a few valuable, perennial works. This is the real threat facing the content industry not content piracy (Downes, 2003b). Vaknin (2004) estimates that there are more than one million books published between 1924 and 1964 in the USA that should be in the public domain. For an online listing of many of the high quality works that are being prevented from entering the public domain (see Karjala, 2003). Duke Law professor James Boyle claims these copyright extensions have "locked up all of 20th century culture . . . to save maybe five percent” (cited in Morgan, 2003). This creates major difficulties for researchers, creators, instructors, and the general public, who wish to avail themselves of this material.

As if the Sonny Bono Act were not enough, the big content and software industries joined forces to support the introduction and successful passage of the Digital Millennium Copyright Act (DMCA). This Act makes it illegal (and even criminal) to circumvent protection mechanisms on software. This includes even the sharing of information on how to circumvent protection (Digital Millennium Copyright Act, 1998). Copyright controllers are determined to assert and extend their 
control. Librarians claim that the DMCA will have serious long term negative effects on research. Bricklin (2002) claims that copy protection could "break the chain necessary to preserve creative works.” He argues that because of the DMCA “To create a 'Rosetta Stone' of today's new formats will be asking to go to jail and having your work banned.” Copy-protected content and applications are less likely to survive for posterity.

Lynch (2001) believes that these legal changes represent a massive change in the balance of control over content. Along with other attempts at control by the big copyright controllers, it has caused enormous difficulties for the development of electronic texts or e-books. Many of the advanced features of e-books have been removed in order to prevent copying. These regressive measures include technical features that limit the downloading of content to the proprietor's site, and suppressing the copy and paste feature, as well as charging excessive prices making e-book purchases less attractive than paper copies. Other controls include publishers withdrawing legitimately purchased subscriptions without notifying the subscribers. Some software licenses limit usage to personal business only, prohibiting any formal educational application. Others prohibit personal use and limit usage to business only. Other licenses restrict use to teaching and learning contexts only. The controllers will want to know who is doing what with their applications.

\section{Who's Stealing from Whom?}

It could be argued that preventing this fount of knowledge from entering the public domain is "taking away" or "stealing" the commons from the goose. Reverend J. Frame wrote "to penalize consumers in order to give special benefit to an industry might well come under the Biblical definition of theft" (Frame, 2002).

Moreover, how much have the copyright controllers really lost in sales from the downloading of text, software, music and video files? Business software companies alone claim that they have lost more than U.S. \$29 billion according to the Business Software Alliance (International Data Corporation, 2004). Kapica (2002) refers to a Forrester Research investigation of the music industry that shows that swapping music MP3s is "not the cause of music industry woes" - the 15 per cent drop in music sales can be traced to recession and competition from DVDs and video games. Music companies and their retailers were fined more than U.S. \$143 million in 2002, after being found guilty of price-fixing CDs (Reporter, 2002). Liebowitz (2004) suggests that illicit copying might actually benefit copyright owners.

Self (2004) provides an economic analysis showing that the figures used by the copyright controllers on the billions of dollars lost are manufactured and highly suspect. He questions their methodologies, which in any case they seldom provide. There is also a strong argument that pirating has bolstered the profits of many companies. For example, MS DOS became an accepted standard because it was copied by everyone with a personal computer. This helped to establish Microsoft as the leading software company (Anonymous Coward, 2004). Self (2004) wonders if Microsoft would really prefer a million installed copies of Linux rather than a million installed pirate copies of Windows.

On the other hand, how much extra money have copyright controllers made from consumers paying full price for music and movies they had already paid full price for only a few years before? I myself, being long in the tooth, have legally purchased the same songs in vinyl 45, LP, 8-track, audio cassette, and CD formats. And, I have recently downloaded some of them in digital format without paying. This is legal in Canada (Department of Justice, 1985). Card (2003) wrote: 
"Strip away all the pretension, and what you really have is this: Rapacious companies that have become bloated on windfall profits and ruthless exploitation of other people's talents are now terrified that the gravy train will go away.”

Other words that copyright controllers use along with "steal" to bolster their argument for pseudo-copyright are "artist" and "author." Whenever they campaign for protecting copyright, it is always for the benefit of the "artist" or "author" and not themselves. These words summon up images of highly respected figures like DaVinci, Michelangelo, Shakespeare, and Mark Twain; whereas, the word "vendor" is not held in as high regard. People tend to have much more sympathy for artists and authors than vendors. The big companies hold themselves up as the defenders of their artists' and authors' rights. The truth is that for most software, books, audio and video content, the lion's share of the profits go to the big companies and not to the artists and authors.

Card (2003) argues that the big content companies' protestations that they are protecting the rights of their artists are a sham. They have been manipulating copyright laws for years, stealing everything they could from the authors and artists who created the content. Movie studios use "creative accounting" to minimize their profits, thus avoiding taxes and depriving the creators of their proper percentage. He refers to these companies as profiteers and bloodsuckers.

Barlow (2002) estimates that nearly 90 per cent of musicians with major label contracts cannot pay up the money advanced to them. The young artists want to be heard so much that they are willing to sell their souls to the big record companies. Albini (1998) gives an informative account of how record companies rip off rock band artists. Avalon (2003) reported that the major recording companies were caught stealing US \$100 million a year from their artists and were severely chastised for doing so by a U.S. federal court judge.

In another action, authors had to file suit with the U.S. Supreme Court to assert their rights to proceeds from the subsequent sales of their works to database services ( New York Times Co. Inc. et al v. Tasini et al. certiori, 2001). More recently, record companies, who normally pay artists from 6 to 8 cents per song, are refusing to pay artists anything more for their "double session" CDs that release the songs in multiple formats. This dispute is being negotiated (Borland, 2004).

A rather contemptible example of the usurpation of an artists' right by the big companies is that of Disney and other recording companies who took over the rights to the hit song "The Lion Sleeps Tonight" otherwise known as "Whinawei" or originally "Mbuba." The original South African song writer, Soloman Linda, died a pauper, although the estimated value of his song is U.S. \$15 million (3rd Ear Music, n.d.; Isa, 2004). Who's stealing from whom?

Content companies crying about the loss of their profits to digital pirates should examine their own history. They tried to stop radio from playing their songs, not realizing that it would be the biggest promoter for record sales. Movie companies attempted to limit the showing of movies on television and TV. Yet, it became a huge aftermarket for their used products extending their life. Card (2003) noted that although B movies and newsreels suffered, the aftermarket for the top hits became very lucrative. The video cassette recorder (VCR) terrified studios and TV executives. At the time of its introduction, Jack Valenti (1983), head of the Motion Picture Association of America commented "the VCR is to the American film producer and the American public as the Boston strangler is to the woman home alone." Yet, the VCR has proved immensely profitable, once the copyright controllers came to terms with rentals and reduced their pricing to sustainable 
levels. Now with DVDs, the aftermarket is often more profitable than the original cinema showing. The only movie theatres to (almost) disappear because of the new technologies are the pornography theatres. And the controllers never learn. To protect their copyright, the Recording Industry Association of America (RIAA) is now pushing for onerous restrictions to limit the capabilities of digital radio (Reuters, 2004).

Ludlow (1996) makes a useful distinction between software pirates and bootleggers. Software pirates make copies for their own use or for distribution among their friends. Through their distribution of software, they actually contribute to the development of the software industry. Software bootleggers, on the other hand, make copies of software for profit, often copying on a large scale. Ludlow argues that pirates are not crooks, hurt no one, and in fact contribute to the software industry. "Most pirates," he argues, "consider bootleggers to be lower life forms than child molesters" (p. 109). In support of this distinction, Litman (2002, p. 132) argues that in the digital world, copying is "an unavoidable incident of reading, listening to, learning from, sharing, improving, and reusing" content and should no longer be considered an appropriate measure of infringement. He contends that the use of the content is a better measure, whether the copying is commercial or non-commercial. Infringement, he maintains, should be related to large-scale interference with or the ability to hinder commercialization (p. 135).

The content companies want full property rights, but they do not want to give traditional property rights to consumers preferring to restrict consumers' traditional rights through different forms of contracts and licensing that restrict the consumer and grant the controllers more flexibility (Adler, 2001). They gain new revenue opportunities and new capabilities for tracking and controlling the post-sale use of their content as well as new business models such as transaction use, based on their ability to impose and enforce rules. Their rules include pay-per-view and limited-time subscriptions providing them with ongoing revenue streams.

One of the most important of the traditional consumer rights is the right of first sale, which is the right of someone, who buys a book or CD to resell it or give it to someone else. Another right is to use their purchase of content in a fair way. These rights are not "extras" but are integral to the copyright and property systems. An irate Rothman (2004) complained: "I'm not talking machineguns and Molotov cocktails, just an uppity assertion of Americans' rights to own books, not merely rent them or otherwise be at the mercy of control-fixated publishers and software companies." Many software buyers are under the illusion that they own what they buy. Not any more. All they own is the $\mathrm{CD}$, the box and the installation instructions.

It is not clear that the sharing of content is illegal or even against the spirit of copyright law, which provides exemptions and recognizes first sale and fair use rights. Young people have been sharing comic books, games, and music with friends for generations. This is not new. Now that it is much easier to exchange in a digital environment, the copyright controllers are trying to restrict it and appropriate consumers' traditional rights. For an ominous story about our future, if the controllers continue see Stallman (1997).

The assault on copyright puts a damper on research activities as Princeton University professor Edward Felten discovered. He had to sue for the right to present a scholarly paper describing the process for breaking a copyright-protection technology. The RIAA backed down, but the entire process was threatening and time consuming, serving as a deterrent to other researchers, with similar interests (Craver, McGregor, Wu, Liu, Stubblefield, Swartzlander, et al., 2001). 


\section{“Contributory” or “Vicarious” Infringement}

In addition to their prosecutions, the owners have also developed the concept of "contributory" or "vicarious" infringement" as a way of downloading the responsibility of enforcing copyright to Internet Service Providers (ISPs), TelCos (RIAA, 2003), universities (Carlson, 2003a; Sherwin, 2003), and others (Jardin, 2004). Zittrain (2002) refers to this as the compulsory "deputizing” of network providers as content police. This is yet another example of the owners demanding the rights of property owners, without taking on the responsibilities. If you own land, it is your responsibility to fence it and keep out trespassers. If someone trespasses on (infringes) another person's land, then it is up to the landowner - not others or the civil authorities - to be responsible for the law's enforcement. A civil case is required.

In the same vein, ISPs are not responsible for the indiscretions of their users. They are simply common carriers, acting as conduits for messages. In a Philadelphia court challenge, the judge noted that material on the Internet has to be deliberately sought out by the viewer, stating "there is immense legal significance to those few clicks" (Cairncross, 1997, p.191). This makes the perpetrators of the misdeed responsible, not the ISPs.

The Technology Education and Copyright Harmonization Act (TEACH Act, 2002) and the recently introduced Protecting Intellectual Rights Against Theft and Expropriation Act (PIRATE Act, 2004) both transfer the responsibility for copyright enforcement from the owners to institutions and the civil authorities respectively. The TEACH Act re-grants rights that universities and other educational institutions have always traditionally held. In order to benefit from the provisions of this Act, and enjoy the rights of fair use that they have always had, educational institutions must ensure that they implement a comprehensive copyright policy. They must then take responsibility for educating faculty and students on the copyright controllers' interpretation of copyright and apply special technological restrictions limiting access to copyrighted works. More burdensome for institutions, they must also take on the responsibility of enforcing the copyright interests of the copyright controllers (Craver et al., 2001). The PIRATE Act will benefit the content owners immensely, transferring the costs of enforcing copyright from them to the taxpayers. Jardin (2004) reports that the bills' sponsors, Senators Leahy and Hatch, are both recipients of major funding from the entertainment industry.

Gregory A. Jackson, Chief Information Officer at the University of Chicago commented: "Fundamentally, these shouldn't be higher-education issues. I'm worried that we are heading down a path that will wildly complicate our lives, all to preserve something that is essentially archaic - the record companies' existing business model of selling CD's and tapes." (Carlson, 2003b). If the entertainment industry has a problem with their copyright, they should handle it themselves and not transfer the responsibility of enforcement onto public institutions and the taxpayers.

These enforcement activities include extrajudicial methods of surveillance that secretly detect, deter, and control acts of consumer infringement. Thus they represent a significant invasion of privacy. Universities are now expected (although not yet obliged by law) to participate with copyright controllers in the surveillance of faculty and students, becoming police and judges and adversely affecting traditional academic freedoms.

As previously mentioned, the European Union with its Directive for the Enforcement of Intellectual Property Rights, combined with injunctions goes far beyond the DMCA. It includes 
patents and it includes all minor, unintentional, and non-commercial infringements of IP (European Union, 2003).

\section{Restoring the Balance}

People like John Perry Barlow of the Electronic Frontier Foundation and Lawrence Lessig are actively campaigning to stop the assault of the big content companies, fighting to restore the balance for the public and educators that was envisioned in the original copyright laws. Lessig took the fight against the Sonny Bono Term Extension Act to the U.S. Supreme Court, but was not successful in his arguments over the meaning of a "limited time" - apparently it can mean "forever less a day" (Levy, 2002). Even Alan Greenspan of the Federal Reserve Bank has called for a restoration of balance (Greenspan, 2004). Horn, Maxwell, and Crawford (2004) refer to a "substantial disconnect between public attitudes toward copyright and the letter of the law" and they too call for a restoration of the balance encouraging, not discouraging innovation. Balance is essential. U.S. County Court Judge Alex Kozinski wrote: "Overprotecting intellectual property is as harmful as under protecting it . . . it stifles the very creative forces it's supposed to nurture" (Morgan, 2003).

Among these "balancing" initiatives is the Public Domain Enhancement Act (2003), which has been introduced into the U.S. Congress. This act proposes to add a nominal fee of U.S. \$1.00 after 50 years for those who wish to renew copyright. This would have the effect of opening up the way for millions of abandoned works with no commercial value to enter the public domain, with the bonus of providing a database of those who register so that people looking for the copyright owners would be able to find them without undue difficulty. Another proposed bill attempting to restore the balance in copyright laws is the appropriately named Balance Act (2003), which represents an attempt to restore fair use rights that have been severely curtailed by the DMCA. The introduction into Congress of the Digital Media Consumers' Rights Act is a minimalist effort to at least ensure that the copyright controllers do not mislabel copy-protected music discs as an unfair method of competition or as a deceptive act or practice (2002).

In Canada, Micheal Geist has proposed that Canada take a unique position that maintains balance and upholds the rights of researchers (Geist, 2004). A Supreme Court decision has done much to restore the balance. Anyone can now make a copy for research without paying a license fee (Won, 2004). In this decision, Chief Justice McLachlin insisted that "fair dealing" was integral to the copyright law, and wrote: "Research must be given a large and liberal interpretation in order to ensure that user's rights are not unduly constrained, and is not limited to non-commercial and private contexts.” (Supreme Court of Canada, 2004; Makin, 2004). The Court has ruled that users' rights prevail in the area of research and that equipment owners are not liable for copyright infringement simply because they authorize the use of their equipment to someone who then violates copyright. The concept of "contributory infringement” does not exist in Canada.

Project Gutenberg (2003) is "the Internet's oldest producer of free electronic books (e-Books or eTexts).” Hundreds of volunteers share the vision of creating digital books and making them freely accessible online. By September 15, 2004, there were more than 13,000 books available. Following in this direction, the Public Library of Science (PLoS), a non-profit organization of scientists and physicians, is launching a public campaign aimed at making the world's scientific and medical literature a public resource (Vanderzee, 2003).

U. S. Congressman Sabo, noting that more than U.S. $\$ 50$ billion dollars is invested by U.S. taxpayers each year in scientific and medical research, has introduced into Congress a bill, the 
"Public Access to Science Act" or the "Sabo bill" that would make all research funded by the U.S. government exempt from copyright protection as are other federal documents (Suber, 2003). This bill enjoys wide support from researchers, including at least 25 American Nobel Prize winters (SPARC-OA Forum, 2004). A special committee of the British Parliament makes a similar recommendation in Scientific Publications: Free for all? (2004), and a European group of scientists is campaigning for similar results (Scientific Information Exchange, 2004).

In fact, many research documents are presently available online, but exist in a "walled garden" accessible to the privileged few who work for organizations that pay exorbitant fees to private companies. The taxpayers have paid for the creation of these documents and then must pay heftily again to access them. Trosow (2003) refers to this as a "double subsidy."

The Open Knowledge Initiative is another well known open commons initiative (Open Knowledge Initiative, 2004). The Creative Commons license represents yet another attempt to restore balance. Compromise and moderation were once the driving forces of a copyright system that valued innovation and protection equally. Their principal goal is "to build a layer of reasonable, flexible copyright in the face of increasingly restrictive default rules" (Creative Commons, 2004). For this, they have released a set of model copyright licenses that are free of charge for public use.

The General Assembly of the World Intellectual Property Association (WIPO) has called on members for fundamental reform, rejecting the present protectionist orientation and returning to the original principals of encouraging learning and promoting development. Citing the "enormous differences in bargaining power", the assembly calls for a return to a more balanced approach between consumers and creators of IP (WIPO, 2004).

\section{Conclusion and Implications for Open and Distance Learning}

This paper argues for a restoration of the traditional balance between the rights of the creators, the rights of the users, and the special rights of educators, which were implicit in the original copyright acts. For links to contrary opinions to my own, interested researchers are advised to consult the links at the websites of these references: (Infoweblinks.com, n. d.; WritingWorld.com, 2004). Also, look at the statutes referred to in the paper. They are available in the references list below or from Billboard.biz (2004) and Chartrand (2000). Also consult the websites of the copyright offices of most universities, where inexplicably, they seem to quite zealously guard the viewpoint of the controllers. See also Bulte (2004), Casey, (2004) and Lipinski (2003).

Distance educators must better understand the origins of copyright law as it was originally intended, and defend it as a vehicle for the promotion of learning, and not as an act to protect authors. Copyright law created the public domain and restricted the control of the copyright owners to a limited time. As open learning becomes more and more digital, the para-copyright burdens being added to the original laws are subverting their intent, transforming them into a vehicle for protection only and undermining the rights of educational institutions and the public domain. Too many copyright offices in too many institutions view copyright as something to be "enforced" and "monitored" rather than as a mechanism for promoting the dissemination of knowledge as it was intended.

The burden placed on institutions delivering electronically because of the present imbalances in the copyright system is quite heavy. The disparate problems are known to content developers in many different institutions. Langlois, Heller, Edwards, Lyratzopoulos, and Sandars (2004) note 
their difficulties in obtaining copyright permissions even from those who were perfectly willing to provide them at no charge. The first difficulty is actually tracing down who owns the copyright. Then, developers have to find the people and arrange for their signatures. They highlight the burden of additional staffing and paperwork generated by the permission process. They also refer to the resultant bias in material towards "readily available" electronic resources because of the lack of co-operation of some publishers. For example, distance education institutions have demonstrated this bias by deciding not to offer music courses (or limit them considerably) because of the costs and complexities involved in obtaining copyright clearances (Industry Canada, 2004a).

Librarians also complain about the problems associated with obtaining clearances for copyrighted works, and that doing so can be "virtually impossible." They specifically point to the enormous difficulties in identifying copyright owners, so much as to discourage all but the most persistent. Licensing is, all too often, too expensive to be considered. The digital copyright is also not the same as the printed matter copyright. Just because a publisher owns the right to print books, does not mean that the author has surrendered his or her digital rights to that publisher. Libraries, even if they can identify the owner, often do not have the power to negotiate fair terms for digital use. They stress that more than anything else, it is the transaction costs associated with clearances and licensing requirements that are the most onerous (Lutzker, 1999). Nor is this always the fault of the creators. It has become nearly impossible for them to avoid the restrictions of the paracopyright laws even if they want to. It is not a simple task to open your work and make it available to all in the public domain (Ebbinghouse, 2002).

Another burden being placed on distance educators is that of "contributory" or "vicarious" infringement. Institutions of learning must now overlook the traditional educational freedoms and implement comprehensive copyright policies, taking on the responsibility for training staff, monitoring, and policing para-copyright as being defined by the content controllers. Now, educational institutions - not the owners - are being made responsible and liable for enforcement.

The principal problem for institutions searching for the copyright owners and participating in enforcement activities is that it takes resources away from the institution that should be used for education. Why should universities be so burdened, accepting the downloading of responsibility for enforcement from the copyright controllers? "Instead of permitting themselves to be drawn down the track of greater and greater surveillance, universities should stand up early and assert their rights to set their own educational priorities” (Electronic Frontier Foundation, n.d.).

Katyal (2004) writes that faculty and students will be inclined to opt for risk-averse behaviours when subjected to surveillance in order to forestall discomforting inquiries by the copyright police. Already, there is a tendency for researchers to avoid references to proprietary content and avoid using language that might be considered to be under copyright protection. Some faculty even avoid linking to particular websites under fear of prosecution. Katyal (2004) notes: "The eventual result would be a gradual chilling of creative behavior; the constant, silent, assertion of surveillance for infringement might eventually deter you from speaking at all.” IP rights are quietly dominating the privacy and creative rights of citizens. Surveillance encourages the "over deterrence of speech and the evisceration of fair use," converting copyright from a simple "copy" right into a regime that governs all speech and expression in cyberspace, even when it is only tangentially related to the copyright owner in question.” She argues that the surveillance activities of the big content companies are "incompletely theorized, technologically unbounded, and, potentially, legally unrestrained.” 
The public domain originated as a direct result of the copyright statutes. The growth of publicly available online content - the learning commons - is the greatest asset available for open learning ever created. The future growth of distance learning is profoundly tied-up with this commons. Distance education research is also becoming more and more dependent on the research that is accessible through the commons. Students and researchers in developing countries and small institutions cannot afford to pay the huge fees demanded by the "walled garden" databases that are symptomatic of the enclosure of the commons. (Neither can the rich large institutions!). Distance educators should support initiatives like Project Gutenberg, the Open Courseware Initiative, and the Open Knowledge Initiative as well as the recent introduction of bills to open up all publicly funded research and make it freely available on the Internet.

For distance education teachers and researchers, these copyright wars are important. The preservation of the public domain as well as our traditional rights to "fair use" or "fair dealing" are worthy goals. We must preserve open access to content. It is essential for promoting education and scientific progress. Like evil trolls guarding the gates, the copyright controllers are trying to hold sway over our actions and create walled gardens around knowledge repositories so that that they can maintain full control over who uses applications or accesses content and when, where, and how they use it. Ironically, this all out assault on open information is happening, just as the Internet has opened up unimaginable opportunities for the free exchange of knowledge and universally accessible education.

The law locks up the man or woman Who steals the goose from off the common And geese will still a common lack Till they go and steal it back.

Anonymous 1764 or 1821

Let's retake the commons.

\section{References}

Digital Millennium Copyright Act, 1122860 105-304 (1998). Retrieved September 24, 2004 from: http://www.loc.gov/copyright/legislation/dmca.pdf

Sony Bono Copyright Term Extension Act, S505 (1998). Retrieved August 21, 2004 from: http://www.copyright.gov/legislation/s505.pdf

Digital Media Consumers' Rights Act, 107(2) (2002). Retrieved August 7, 2004 from: http://www.house.gov/boucher/docs/BOUCHE_ 025.pdf

Technology Education and Copyright Harmonization (TEACH) Act, 107-687 S487 (2002).

Retrieved September 2, 2004 from: http://thomas.loc.gov/

Benefit Authors without Limiting Advancement or Net Consumer Expectations (BALANCE ) Act, H. R. 1066 Cong. Rec. (2003). Retrieved September 13, 2004 from: http://thomas.loc.gov/cgi-bin/query/z?c108:H.R.1066:

Public Domain Enhancement Act (2003). Retrieved September 12, 2004 from: http://www.eldred.cc/eablog/TheBill.pdf 
Protecting Intellectual Rights Against Theft and Expropriation (PIRATE) Act, S2237 (2004). Retrieved September 2, 2004 from: http://thomas.loc.gov/cgi-bin/bdquery/

Scientific Publications: Free for all? House of Commons (UK), 2003-2004, Sess. HC 399-I (2004). Retrieved July 20, 2004 from: http://www.parliament.uk/parliamentary_committees/

3rd Ear Music. (n.d.). Where does the lion sleep tonight? Retrieved September 1, 2004 from: http://www.3rdearmusic.com/forum/mbube2.html

Adler, A. (2001, June 27). Statement of Allan R. Adler vice president for legal and governmental affairs Association of American Publishers before the Subcommittee on courts, the Internet and intellectual property House Judiciary Committee concerning S.487 "The Technology, Education And Copyright Harmonization Act Of 2001.” Retrieved September 20, 2004 from: http://www.publishers.org/home/congrpt/h487testimony.htm

Albini, S. (1998, February 6). The problem with music. Retrieved October 31, 2002 from: http://mitvma.mit.edu/ mhb/ALBINI.HTML

Anonymous Coward. (2004, August 15). I confess. I'm a software pirate. Retrieved September 3, 2004 from: http://www.peerfear.org/rss/permalink/2004/08/15/IConfessIMASoftwarePirate/

Aristotle. (2004, April). The Poetics. Retrieved September 9, 2004 from: http://www.authorama.com/the-poetics-5.html

Associated Press. (2004, June 28). Sovereign Iraqi government sworn into power [Electronic version]. Globe and Mail. Retrieved June 28, 2004 from: http://www.globeandmail.com/servlet/story/

Australian Government Department of Foreign Affairs and Trade. (2004). Australia-United States Free Trade Agreement: Intellectual property. Retrieved September 11, 2004 from: http://www.dfat.gov.au/trade/

Avalon, M. (2003, May 1). Major labels caught stealing \$100m a year: Record clubs get a smack upside the head by federal judge. Retrieved May 11, 2003 from: http://musicdish.com/mag/?id=8048

Barlow, J. P. (1994, March). The economy of ideas [Electronic version]. Wired, 2(03). Retrieved September 10, 2004 from: http://www.wired.com/wired/archive/2.03/economy.ieda.html

Barlow, J. P. (1996). Selling wine without bottles: The economy of mind on the global net. In High noon on the electronic frontier: conceptual issues in cyberspace (pp. 9 - 34). Cambridge MA: MIT Press.

Barlow, J. P. (2002). Intellectual property, information age. In A. Thierer and C. W. Crews, Jr. (Eds.), Copyfights: The future of intellectual property in the information age (pp. 37 41). Washington, D.C.: Cato Institute. 
Bell, T. W. (2002). Indelicate imbalancing in copyright and patent law. In A. Thierer and C. W. Crews, Jr. (Eds.), Copyfights: The future of intellectual property in the information age (pp. 1 - 16). Washington, D.C.: Cato Institute.

Billboard.biz. (2004). Document room. Retrieved September 20, 2004 from: http://www.billboard.com/bb/biz/research/document_room/index.jsp

Black, J. (2002, September 27). A case to define the digital age. Business Week Online. Retrieved August 22, 2004 from: http://www.businessweek.com/technology/content/sep2002/tc20020927_7367.htm

Bloom, J. (2002, November 22). Right and wrong: The copy-right infringement [Electronic version]. National Review Online. Retrieved December 3, 2002 from: http://www.nationalreview.com/comment/comment-bloom112202.asp

Bollier, D. (2003). Silent theft: The private plunder of our common wealth. New York: Routledge.

Borland, J. (2004, January 14). Rights issue dogs CD protection [Electronic version]. Globe and Mail. Retrieved January 16, 2004 from: http://www.globetechnology.com/servlet/story/

Bricklin, D. (2002). Copy protection robs the future. Retrieved September 25, 2002 from: http://www.bricklin.com/robfuture.htm

Bulte, S. D. (2004, May). Interim Report on Copyright Reform: Report of the Standing Committee on Canadian Heritage. Retrieved September 1, 2004 from: http://www.parl.gc.ca/InfocomDoc/Documents/

Cahill, T. (1995). How the Irish saved civilization: The untold story of Ireland's heroic role from the fall of Rome to the rise of medieval Europe (Vol. I). New York: Doubleday.

Cairncross, F. (1997). The death of distance: how the communications revolution will change our lives.London: Orion Publishing Group Ltd.

Card, O. S. (2003, September 7). Art watch. The Ornery American. Retrieved December 29, 2003 from: http://www.ornery.org/essays/warwatch/2003-09-07-1.html

Carlson, S. (2003a, April 2). Penn State Provost warns students that they could go to prison for illegal file sharing [Electronic version]. Chronicle of Higher Education. Retrieved April 4, 2003 from: http://chronicle.com/free/2003/04/2003040201t.htm

Carlson, S. (2003b, May 23). A president tries to settle the controversy over file sharing: Penn State's Graham Spanier wants to make a deal with the music industry [Electronic version]. Chronicle of Higher Education, 49(37), A27. Retrieved May 18, 2003 from: http://chronicle.com/free/v49/i37/37a02701.htm

Casey, J. (2004, July). Intellectual property rights (IPR) in networked e-learning: A beginners guide for content developers. JISC Legal Information Service. Retrieved October 4, 2004 from: http://www.jisclegal.ac.uk/publications/johncasey_1.htm 
Chartrand, H. H. (2000, Fall). Copyright C.P.U.: Creators, proprietors and users [Electronic version]. Journal of Arts Management, Law \& Society, 30(3). Retrieved September 7, 2004 from: http://www.culturaleconomics.atfreeweb.com/cpu.htm

Cisneros, O. S. (1999, July 27). Universal: Don't link to us. Wired News. Retrieved August 19, 2004 from: http://www.wired.com/news/politics/0,1283,20948,00.html

Concannon, K. (2004, July 1). St. Columcille: Ireland's first 'White Martyr' [Electronic version]. Catholic Herald. Retrieved August 20, 2004 from: http://www.catholicherald.com/articles/04articles/columcille.htm

Craver, S. A., McGregor, J. P., Wu, M., Liu, B., Stubblefield, A., Swartzlander, B., et al. (2001, July). Reading between the lines: Lessons from: the SDMI Challenge [Electronic version]. Wired, 9(07), 61 - 63. Retrieved September 10, 2004 from: http://cryptome.org/sdmi-attack

Creative Commons. (2004). Creative Commons home page. Retrieved September 6, 2004 from: http://creativecommons.org/learn/

Davis, J. (2004, May 2). Arizona open range laws \& cattle theft? Retrieved September 1, 2004 from: http://www.azod.com/SpeakingOut/2004/Q2/

Department of Justice (Canada). (1985, August 31, 2002). Copyright Act (R.S. 1985, c. C-42). Retrieved March 20, 2003 from: http://laws.justice.gc.ca/en/C-42/

Downes, S. (2003a, April). Copyright, ethics and theft [Electronic version]. Journal of the United States Distance Learning Association, 17(2). Retrieved May 13, 2003 from: http://www.usdla.org/html/journal/ED_APR03.pdf

Downes, S. (2003b, December 30). The turning point: Attacking open content. Retrieved January 4, 2004 from: http://www.downes.ca/

Ebbinghouse, C. (2002, Nov/Dec 2002). Just can't hardly give it away: Generosity versus copyright [Electronic version]. Searcher, 10(10). Retrieved November 15, 2002 from: http://www.infotoday.com/searcher/nov02/ebbinghouse2.htm

Editors. (2004, August). Stationers Company. Literary Encyclopedia. Retrieved September 7, 2004 from: http://www.litencyc.com/php/stopics.php?rec=true\&UID=1309

Electronic Frontier Foundation. (n.d.). Universities should resist network monitoring demands. Retrieved September 10, 2004 from: http://www.eff.org/IP/P2P/universitymonitoring.pdf

English Nature. (2004). Sheep and Wildlife Enhancement Scheme - sustaining wildlife and sheep farming Information Note 1 - The National Picture, 2004. Retrieved September 1, 2004 from: http://www.english-nature.org.uk/pubs/publication/PDF/swesinfo1.pdf 
European Union. (2003, January 30). Proposed directive on enforcement of intellectual property rights: frequently asked questions. Retrived September 18, 2003 from: http://europa.eu.int/rapid/start/

Forté, B. (2000, June 15). The Statute of Queen Anne. Retrieved September 1, 2004 from: http://betweenborders.com/queenanne/

Frame, J. M. (2002, April 17). A distinguished theologian looks at copyright ethics and the fair use of technology: The other shoe: Copyright and the reasonable use of technology. Retrieved July 6, 2003 from: http://www.applelinks.com/articles/2002/04/20020417131622.shtml

Geist, M. (2004, September 17). A balanced approach to reforming copyright law [Electronic version]. University Affairs. Retrieved October 4, 2004 from: http://www.universityaffairs.ca/issues/2004/october/copyright_law_01.html

Gittins, R. (2004, August 11). Just what are we giving away? [Electronic version]. The Age. Retrieved September 21, 2004 from: http://www.theage.com.au/articles/2004/08/10/1092102446841.html?oneclick=true

Greenspan, A. (2004, February 27). Intellectual property rights: Remarks at the Stanford Institute for Economic Policy Research Economic Summit. Retrieved September 1, 2004 from: http://www.federalreserve.gov/

Hardin, G. (1968, December 13). The tragedy of the commons [Electronic version]. Science, 162, 1243 - 1248. Retrieved August 20, 2004 from: http://dieoff.org/page95.htm

Harpur, T. (2004). The Pagan Christ: Recovering the Lost Light.Toronto: Thomas Allen.

Horn, P., Maxwell, E., and Crawford, S. (2004). Promoting Innovation and Economic Growth: The Special Problem of Digital Intellectual Property. Retrieved September 1, 2004 from: http://www.ced.org/docs/report/report_dcc_v2.pdf

House of Commons. (1709). An Act for the Encouragement of Learning, by Vesting the Copies of Printed Books in the Author's or Purchasers of Such Copies. Retrieved October 28, 2003 from: http://press-pubs.uchicago.edu/founders/documents/a1_8_8s2.html

Howard, R. M. (1988). Review of Mallon, Thomas. Stolen Words: Forays into the origins and ravages of plagiarism. New York: Ticknor and Fields, 1989. Retrieved September 9, 2004 from: http://english.ttu.edu/kairos/3.1/reviews/howard/mallon.html

Indiana University. (2004, September 10). Digital Library of the Commons. Retrieved September 6, 2004 from: http://dlc.dlib.indiana.edu/

Industry Canada. (2004a, January 1). Assessing the economic impact of copyright reform in the area of technology-enhanced learning. Retrieved September 25, 2004 from:

http://strategis.ic.gc.ca/epic/Internet/inippd-dppi.nsf/en/ip01104e.html 
Industry Canada. (2004b, February 17). Presentations on the Canadian intellectual property regime. Retrieved September 6, 2004 from: http://strategis.ic.gc.ca/epic/Internet/inippddppi.nsf/en/ip01080e.html

Infoweblinks.com. (n. d.). Copyright and piracy. Retrieved October 4, 2004 from: http://www.infoweblinks.com/content/copyright-piracy.htm

International Data Corporation. (2004, July 4). Global software piracy study. Retrieved September 3, 2004 from: http://www.bsa.org/globalstudy/

Isa, M. (2004, July 2). A flap over “The Lion Sleeps Tonight.” Reuters. Retrieved July 12, 2004 from: http://www.reuters.com/

Jardin, X. (2004, March 26). Congress moves to criminalize P2P. Wired News. Retrieved March 27, 2004 from: http://www.wired.com/news/digiwood/0,1412,62830,00.html

Jaszi, P. (2001, May 29). Intellectual property legislative update:Copyright, paracopyright, and pseudo-Copyright. Retrieved May 20, 2003 from: http://www.arl.org/arl/proceedings/132/luncheon/jaszi.html

Jefferson, T. (1813, August 13). Thomas Jefferson letter to Isaac McPherson 13:333--34 [Electronic version]. Foundation Constitution, 16(25). Retrieved August 21, 2004 from: http://press-pubs.uchicago.edu/founders/documents/v1ch16s25.html

Jesdanun, A. (2001, August 9). Freedom to link: A fundamental premise of the Web is challenged [Electronic version]. Detroit News. Retrieved August 19, 2004 from: http://www.detnews.com/2002/technology/0206/11/technology-510823.htm

Kapica, J. (2002, August 13). MP3s not source of music industry woes: Study [Electronic version]. Globe and Mail. Retrieved September 25, 2004 from: http://www.theglobeandmail.com/

Karjala, D. S. (2003, January 31). Some famous works and year of first publication (subverted public domain list). Retrieved August 8, 2003 from: http://homepages.law.asu.edu/

Katyal, S. K. (2004, April). The New Surveillance [Electronic version]. Case Western Law Review, 54(297). Retrieved April 30, 2004 from: http://ssrn.com/abstract=527003

Khan, B. Z. (2004, February). Does copyright piracy pay? The Effects of U.S. International Copyright Laws on the Market for Books, 1790-1920: NBER Working Paper No. w10271. National Bureau of Economic Research. Retrieved October 4, 2004 from: http://www.nber.org/papers/W10271

Langlois, M., Heller, R. F., Edwards, R., Lyratzopoulos, G., and Sandars, J. (2004, April 7). Restrictions impeding web-based courses: a survey of publisher's variation in authorising access to high quality on-line literature [Electronic version]. BMC Medical Education, 4(7). Retrieved April 15, 2004 from: http://www.biomedcentral.com/1472-6920/4/7/ 
Levy, S. (2002, September 25). Lawrence Lessig's supreme showdown [Electronic version]. Wired, 10(10). Retrieved October 3, 2002 from:

http://www.wired.com/wired/archive/10.10/lessig.html

Liebowitz, S. J. (2004, June 8). Copyright issues, copying and MP3 downloading. Retrieved October 4, 2004 from: http://www.utdallas.edu/ liebowit/intprop/main.htm

Lipinski, T. A. (2003). Legal issues in the development and use of copyrighted material in webbased education. In M. G. Moore \& W. G. Anderson (Eds.), Handbook of distance education (pp. 481 - 503). Mahwah, NJ: Lawrence Erlbaum Associates.

Litman, J. (2002). Revising copyright law for the information age. In A. Thierer \& C. W. Crews, Jr. (Eds.), Copyfights: The future of intellectual property in the information age (pp. 125 145). Washington, D.C.: Cato Institute.

Locke, J. (1692, January 2). A letter to Clarke. Retrieved September 6, 2004 from: http://orion.mt.tama.hosei.ac.jp/hideaki/twocopy.htm

Ludlow, P. (Ed.). (1996). High noon on the electronic frontier: Conceptual issues in cyberspace.Cambridge MA: MIT Press.

Lutzker, A. P. (1999, March 8). Primer on the Digital Millenium: What the Digital Millenium Copyright Act and the Copyright Extension Act mean for the library community. Retrieved September 10, 2003 from: http://www.arl.org/info/frn/copy/primer.html

Lyman, P., and Varian, H. R. (2003). How much information? Retrieved September 6, 2004 from: http://www.sims.berkeley.edu/research/projects/

Lynch, C. (2001, May 28). The battle to determine the future of the book in the digital world. First Monday, 6 (6), 66. Retrieved September 30, 2004 from: http://firstmonday.org/issues/issue6_6/lynch/index.html

Macavinta, C. (1997, May 19). Sidewalk sidesteps Ticketmaster. CNET News.com. Retrieved August 19, 2004 from: http://news.com.com/2100-1023-279913.html?tag=rn

Makin, K. (2004, March 5). Ruling rejects licensing fees:Those making single copies of judgments for research purposes will not have to pay. http://www.globeandmail.com/servlet/ArticleNews/

McDonald, I. (1997). Copyright and intellectual property concerns of Australia's indigenous people. Retrieved September 6, 2004 from: http://www.copyright.org.au/PDF/Articles/A97n12.pdf

Merriam-Webster. (2004). Merriam Webster Online: steal. Retrieved September 3, 2004 from: http://dictionary.oed.com/

Morgan, F. (2003, December 3). Copywrong: Copyright laws are stifling art, but the public domain can save us [Electronic version]. Independent. Retrieved December 5, 2003 from: http://www.indyweek.com/durham/2003-12-03/cover.html 
Nadin, M. (1997). The civilization of illiteracy. Retrieved September 3, 2004 from: http://digital.library.upenn.edu/webbin/gutbook/lookup?num=2481

Naughton, J. (2003, February 9). Intellectual property is theft. Ideas are for sharing [Electronic version]. The Observer. Retrieved February 25, 2003 from: http://www.observer.co.uk/business/story/0,6903,891687,00.html

Open Knowledge Initiative. (2004). OKI home page. Retrieved September 26, 2004 from: http://www.okiproject.org/

Oram, A. (Ed.). (2001). Peer to peer: Harnessing the power of disruptive technologies. Sebastopol, CA: O'Reilly and Associates.

Oxford University Press. (1989). Oxford English Dictionary: steal. Retrieved September 1, 2004 from: http://dictionary.oed.com/

Oxford University Press. (n.d.). Oxford English Dictionary: plagiarize. Retrieved September 9, 2004 from: http://0-dictionary.oed.com.aupac.lib.athabascau.ca/cgi/entry/00180580

Paine, A. B. (Ed.). (1917). Mark Twain's letters.New York: Harper and Brothers.

Project Gutenberg. (2003, May 3). What is project Gutenberg? Retrieved June 25, 2004 from: http://promo.net/pg/

Reporter. (2002, November 22). Efforts to stop music piracy 'pointless' [Electronic version]. BBC News. Retrieved November 23, 2002 from: http://news.bbc.co.uk/2/hi/technology/2502399.stm

Reuters. (2004, June 11). RIAA seeks digital radio copying limits. CNET News.com. Retrieved June 12, 2004 from: http://news.com.com/2100-1027_3-5232048.html

Recording Industry Association of America RIAA. (2003). What the RIAA Is doing about piracy. Retrieved September 1, 2004 from: http://www.riaa.com/issues/piracy/riaa.asp

Rothman, D. (2004, October 10). The Microsoft Reader crack: The lowdown from 'Winston Smith,' Convert Lit coder. Retrieved September 1, 2004 from: http://www.teleread.org/blog/2003 $10 \quad 05$ archive.html

Rupley, S. (2004, March 3). The nuclear weapon of digital rights law: Europe set to establish restrictive copyright legislation [Electronic version]. PC Magazine. Retrieved March 14, 2004 from: http://abcnews.go.com/sections/scitech/ZDM/EU_digital_rights_pcmag_040302.html

Scientific Information Exchange. (2004, March 30). ScIX Project Home Page. Retrieved September 6, 2004 from: http://www.scix.net/

SearchSecurity.com. (2004, August 14). Walled garden. Retrieved September 1, 2004 from: http://searchsecurity.techtarget.com/sDefinition/0,sid14_gci554703,00.html 
Self, K. M. (2004, April 11). On software "piracy”, lies, BSA, Microsoft, rocks, and hard penguins. Retrieved September 3, 2004 from:

http://kmself.home.netcom.com/Rants/piracy.html

Sherwin, A. (2003, March 28). Universities to be sued over music downloads [Electronic version]. Times Online. Retrieved March 28, 2003 from: http://www.timesonline.co.uk/article/0,2-625793,00.html

Shirata, H. (1992). The origin of two American copyright theories: A case of the reception of English law. Retrieved September 6, 2004 from: http://orion.mt.tama.hosei.ac.jp/hideaki/twocopy.htm

SPARC-OA Forum. (2004, August 30). An open letter to the U.S. Congress signed by 25 Nobel Prize winners. Retrieved September 10, 2004 from: https://mx2.arl.org/Lists/SPARCOAForum/Message/991.html

Stallman, R. M. (1997, February). The right to read [Electronic version]. Communications of the ACM, 40(2). Retrieved March 14, 2004 from: http://www.gnu.org/philosophy/right-toread.html

Suber, P. (2003, no date). Sabo bill sparks copyright controversy. Retrieved September 1, 2004 from: http://www.biomedcentral.com/openaccess/

Supreme Court of Canada. (2004, March 4). CCH Canadian Ltd. v. Law Society of Upper Canada. Retrieved September 2, 2004 from: http://www.lexum.umontreal.ca/

Surowiecki, J. (2002, January 21). Righting copy wrongs [Electronic version]. New Yorker. Retrieved September 25, 2004 from: http://www.newyorker.com/

Thomas, J. B. (2004). St. Columba [Electronic version]. The Catholic Encyclopedia, Volume IV. Retrieved March 25, 2004 from: http://www.newadvent.org/cathen/04136a.htm

Trosow, S. E. (2003, September 7). Copyright protection for federally funded research: Necessary incentive or double subsidy? Retrieved September 1, 2004 from: http://publish.uwo.ca/ strosow/Sabo_Bill_Paper.pdf

U.S. Congress. (1998, October 7). Mrs. Bono's address to the House [Electronic version]. Congressional Record House, 144(H9952). Retrieved August 22, 2004 from: http://frwebgate.access.gpo.gov/

U.S. Constitutional Convention. (1787). Constitution of the United States. Retrieved September 1, 2004 from: http://www.law.cornell.edu/constitution/constitution.articlei.html\#section8

U.S. Department of Commerce. (2004, June 4). Business guide for Iraq. Retrieved September 11, 2004 from: http://www.export.gov/iraq/bus climate/businessguide_current.html

U.S. Department of State. (2004, May 3). U.S. releases 2004 report on intellectual property protection. Retrieved September 11, 2004 from: http://usinfo.state.gov/ei/Archive/2004/May/03-429506.html 
Dowling v. United States, No. 84-589. 473 U.S. 207 U.S. Supreme Court (1985). Retrieved August 14, 2004 from: http://caselaw.lp.findlaw.com/scripts/

New York Times Co. Inc. et al v. Tasini et al. certiori, No. 00-201 United States Court of Appeals for the Second Circuit (2001). Retrieved August 21, 2004 from:

http://supct.law.cornell.edu/supct/html/00-201.ZS.html

United Nations. (n.d.). World Intellectual Property Organization. Retrieved September 20, 2004 from: http://www.wipo.int/

Vaidhyanathan, S. (2001). Copyrights and copywrongs: the rise of intellectual property and how it threatens creativity. New York: New York University Press.

Vaknin, S. (2004, January 7). Project Gutenberg's anabasis. Retrieved January 12, 2004 from: http://www.upi.com/view.cfm?StoryID=20040106-041656-1684r

Valenti, J. (1983, April 12). Home Recordings of Copyrighted Works Hearings [Electronic version]. The Subcommittee on Courts, Civil Liberties, and the Administration of Justice of the Committee of the Judiciary. Retrieved July 12, 2003 from: http://cryptome.org/.

Vanderzee, K. (2003, June 26). Public Library of Science acts to increase public access to scientific research; New Bill will ensure public access to federally funded research results. Retrieved September 1, 2004 from:

http://www.plos.org/news/announce_wings.html

Washington, G. (1790, July 17). The First U.S. Copyright Law [Electronic version]. Columbian Centinel. Retrieved August 21, 2004 from:

http://earlyamerica.com/earlyamerica/firsts/copyright/

Wilder, C. (2000, August 21). The Wilder side: Music industry's long, strange trip [Electronic version]. Information Week. Retrieved August 20, 2004 from:

http://www.informationweek.com/800/00uwcw.htm

WIPO. (2004, October 4). Geneva Declaration on the future of the World Intellectual Property Organization. Retrieved October 10, 2004 from:

http://www.cptech.org/ip/wipo/genevadeclaration.html

Won, S. (2004, March 8). Court's copyright ruling in spotlight: Implications likely include business related to Internet [Electronic version]. Globe and Mail. Retrieved March 9, 2004 from: http://www.theglobeandmail.com/servlet/ArticleNews/

WritingWorld.com. (2004). Rights, contracts and copyright. Retrieved October 4, 2004 from: http://www.writing-world.com/rights/index.shtml

Zittrain, J. (2002, November 24). Calling off the copyright war: In battle of property vs. free speech, no one wins [Electronic version]. Boston Globe, D12. Retrieved December 2, 2002 from: http://www.boston.com/dailyglobe2/ 
